\title{
A katolikus egyház szerepe a fogyatékossággal élők esélyegyenlőségének előmozdításában
}

\section{UJHÁZI LÓRÁND ${ }^{1}$}

Helyes európai szocializációnk folytán a fogyatékossággal élö emberekhez azzal a tisztelettel és elfogadással fordulunk, amely őket megilleti. Jogrendszerünk pedig különös figyelmet fordít jogaik védelmére. Fontos garanciális elem az úgynevezett pozitív diszkrimináció elve, amely állapotuk figyelembevétele mellett, a lehetö legtöbb olyan többletjogosítvánnyal ruházza fel őket, amelyek segitségével többi polgártársaikhoz (közel) egyenlö eséllyel indulhatnak az életben. Az európai attitüd és jogvédelem kialakulásában azonban kulcsszerepet játszott a kereszténység és azon belül a katolikus egyház. Ebben a tanulmányban azt bizonyítom, hogy az európai jogvédelmi mechanizmus érthetetlen a katolikus egyház betegekröl szóló tanitása nélkül. Hipotézisemet teológiai, kánonjogi, eszmetörténeti és müvészeti szempontból igazolom. Különös hangsúlyt fektetek az alapjogi aspektusok és az egyház jelenlegi teológiai tanítása közötti különbözőségekre is, ami legkézzelfoghatóbban a magzati élet védelme területén ölt testet.

Kulcsszavak: fogyatékossággal élők, katolikus egyház, kánonjog, egyháztörténelem

\section{The Role of the Catholic Church in Promotion of Equal Opportunities for People with Disabilities}

Due to our proper socialisation, we turn to the disabled with the respect and acceptance that they deserve. Furthermore, our system of law pays special attention to the protection of their rights. The principle of positive discrimination is a highly important safeguard: it entitles them - along considering their conditions - to the most possible additional licences with which they can start their lives with (nearly) the same chances as their fellow citizens. Christianity, including the Catholic Church, played a key role in developing European attitude and right protection. In this study I am proving that the European right protection mechanism cannot be understood without the teaching of the Catholic Church on sick people. I am verifying my hypothesis from the points of view of theology, Canon Law, history of ideas and of arts. I am emphasising the differences between the aspect of fundamental

1 Tudományos főmunkatárs, Nemzeti Közszolgálati Egyetem, e-mail: ujhazi.lorand@uni-nke.hu 
law and the current theological teaching of the Church, which materialise the most clearly in the protection of the unborn child's right to life.

Keywords: the disabled, the Catholic Church, Canon Law, the history of the Church

Pieter Bruegel a holland reneszánsz kiemelkedő alakja. Festészete az emberi élet, a korabeli városok és ünnepek pillanatfelvételei. Képeiről nem hiányoznak a mosolyok és a vidámság markáns ecsetnyomai. ${ }^{2}$ Mondhatnánk, művészete ezer színben adja vissza a hétköznapi élet vidámságát és örömeit. Ezért is olyan kontrasztos az az egyetlen Bruegel-kép, amelyet a Louvre-ban láthatunk, és amely a Koldusok vagy más néven Nyomorékok címet viseli. ${ }^{3}$ Legnaturalisztikusabban ezt a képet egy szóval így lehet összefoglalni: valóság. Reálisan tárja elénk azt a helyzetet, amely még a 16. században is jellemezte a testi fogyatékossága miatt a társadalom perifériájára szorult ember életét. Nemhogy a napjainkban nagyra értékelt esélyegyenlőség fogalma nem létezett, hanem a többi polgár életszínvonalát meg sem közelítő körülmények között éltek. ${ }^{4}$ A 20. század második fele jelentős változást hozott. Egyrészt mind a nemzetközi, ${ }^{5}$ mind a hazai jogrendszerek integráns részévé váltak a fogyatékossággal élők életét megkönnyítő jogszabályi rendelkezések. ${ }^{6}$ Másrészt a negatív meg-

2 Walter S. Gibson: Pieter Bruegel and the Art of Laughter. Berkeley, University of California Press, 2006.

3 Peter Russell: Complete Works of Pieter Bruegel the Elder. Kindle edition, 2016.

4 A történeti aspektushoz lásd Kálmán Zsófia - Könczei György: A Taigetosztól az esélyegyenlőségig. Budapest, Osiris, 2012; Kriskó Edina: Fogyatékokkal élőkkel történö bánásmód a hivatalban. Budapest, Nemzeti Közszolgálati Egyetem, 2014.

5 Az Emberi Jogok Egyetemes Nyilatkozata; Egyezmény a gyermekek jogairól; Polgári és Politikai Jogok Nemzetközi Egyezségokmánya; A Gazdasági, Szociális és Kulturális Jogok Nemzetközi Egyezségokmánya; Fogyatékossággal élő személyek jogairól szóló Egyezmény és az ahhoz kapcsolódó Fakultatív Jegyzőkönyv. Európai uniós dokumentumok: Európai Unió Alapjogi Chartája; Európai Egyezmény az emberi jogok és alapvető szabadságok védelméről; Európai Szociális Charta; Az Európai Unió Tanácsának Irányelve (2000/78/EK) a foglalkoztatás és a munkavégzés során alkalmazott egyenlő bánásmód általános kereteinek létrehozásáról; ResAP(2001)1 Határozat az egyetemes tervezés alapelveinek az épített környezet alakításával foglalkozó valamennyi szakma képzési tervébe történő bevezetéséről (Tomari Határozat); A fogyatékossággal élők életminőségének javítása: a teljes körü részvételre irányuló és annak révén müködő politika erősítése (Malaga, Spanyolország, 2003. május 7-8.); Madridi Nyilatkozat a befogadó társadalom alapja a diszkriminációmentességgel párosuló pozitív cselekvés; Európai Fogyatékosságügyi Stratégia 2010-2020; A fogyatékossággal élő emberek társadalmi befogadása - Európa esélyegyenlőségi stratégiája.

6 Magyarország Alaptörvénye; 1993. évi III. törvény a szociális igazgatásról és szociális ellátásokról; 1998. évi XXVI. törvény a fogyatékos személyek jogairól és esélyegyenlőségük biztosításáról; 1999. évi C. törvény az Európai Szociális Karta kihirdetéséről; 2003. évi CXXV. törvény az egyenlő bánásmódról és az esélyegyenlőség előmozdításáról; 2007. évi XCII. törvény a Fogyatékossággal élő személyek jogairól szóló egyezmény és az ahhoz kapcsolódó Fakultatív Jegyzőkönyv kihirdetéséről; 2009. évi CXXV. törvény a magyar jelnyelvről és a magyar jelnyelv használatáról; 38/2011. (VI. 29.) NEFMI rendelet a Jelnyelvi Tolmácsok Országos Névjegyzékéről; 62/2011. (XI. 10.) NEFMI rendelet a jelnyelvi tolmácsszolgálatok működésének és a jelnyelvi tolmácsszolgáltatás igénybevételének 
különböztetést tiltó (adott esetben szankcionáló) jogszabályi rendelkezések mellett a „diszkrimináció” fogalma pozitív megközelítéssel bővült. Eszerint, lehetőség van arra, hogy szükséges többletjogokat és lehetőségeket biztosítsanak azok számára, akik fogyatékosságaik miatt hátrányosabb helyzetből indulnak az életben. Csak akkor lehet igazi eredményekről beszélni azonban, ha a jogrendszer alapparadigmái és védő-támogató jogszabályhelyei a társadalom legapróbb szövetét is átjárják. Nemcsak ügyes jogalkalmazásról és jogharmonizációról van szó a fogyatékossággal élők érdekében. A fogyatékossággal élők védelme érdekében elengedhetetlen az állam és a nemzetközi közösség fórumaiban rejlő lehetőségekkel élni, de a jog érvényesülésénél mélyebb, a személyt és a humánumot, azon keresztül a társadalom teljes szövevényét érintő területről van szó. Keresve sem lehetne erre vonatkozóan autentikusabb szavakat találni, mint Ferenc pápa fogyatékossággal élők világnapján elhangzó üzenetét:

„A szenvedő emberek befogadása vagy kirekesztése meghatározza valamennyi gazdasági, politikai, társadalmi és vallási projektet. Naponta szembe találjuk magunkat a döntéssel: irgalmas szamaritánusok leszünk vagy közömbösen tovább haladó járókelők?”

Ebben a tanulmányban a katolikus egyház jogalkotásának, megnyilatkozásainak és gyakorlatának a hatását mutatom be a fogyatékossággal élők esélyegyenlőségének megteremtésére és a társadalom érzékenyítésére. Hipotézisem szerint az európai társadalmakban megalkotott esélyegyenlőség értelmezéséhez elengedhetetlen a kereszténység és különösen a katolikus egyház fogyatékossággal élők irányába való megnyilvánulásainak ismerete. Elöljáróban megjegyzem, hogy amikor a történelmi példákat és egyházi szövegeket alkalmazom, akkor a szegénygondozás általános kategóriája alatt a fogyatékossággal élőkkel való törődést is értem. Illetve, a források használatánál alkalmazkodom az eredeti kifejezésekhez, amelyek azonban még nem mindenben felelnek meg annak a jogos elvárásnak, hogy a fogyatékossággal élők számára a legkevésbé legyenek bántók.

\section{A fogyatékossággal élők támogatásának teológiai alapjai}

A Római Birodalmat nemcsak az etnicitás, hanem vallási szempontból is a pluralizmus jellemezte. Hogy milyen út vezetett a kereszténység bevett, majd államvallássá válásához, arról a vallástörténészeknek számos teóriája létezik. Az egymással

feltételeiről; 2013. évi V. törvény a Polgári Törvénykönyvről; 1653/2015. (IX. 14.) Korm. határozat az Országos Fogyatékosságügyi Program végrehajtásának 2015-2018. évekre vonatkozó Intézkedési Tervéről; A Kormány 1257/2011. (VII. 21.) Korm. határozat a fogyatékos személyek számára ápolást-gondozást nyújtó szociális intézményi férőhelyek kiváltásának stratégiájáról és a végrehajtásával kapcsolatos kormányzati feladatokról.

7 Gedő Âgnes: Pápai üzenet a fogyatékossággal élők világnapjára: Befogadóbb világot építsünk a járvány után. Vatican News, 2020. december 5. 
versengő domináns vallások közül győztesen kikerülő kereszténység elméletétől ${ }^{8}$ a haderőt meghódító kereszténység tanán keresztül,9 egészen a biztonsági kihívásokra helyesen reflektáló politikai kereszténységig számos elképzelés létezik.

Maróth Miklós számos előadásában kifejtette, hogy a kereszténység sikere nem az említett szempontokban keresendő. ${ }^{10}$ Maróth úgy látja, hogy a kereszténység olyan „Szociális” hálót épített ki, amellyel egyetlen más vallási közösség sem rendelkezett. A komoly szociális gondoskodás nélküli Római Birodalomban pedig vonzóvá vált a társadalom perifériáján élők számára az a vallás, amely szociális gondoskodást nyújt számukra. Az úgynevezett társadalom perifériájára szorultak között, a dolog természete szerint tömegével voltak különböző „fogyatékkal” élő személyek. Ök alkották azt a társadalmi osztályt, amely teljesen kiszolgáltatott volt közössége és a családja jóindulatának.

A pogány Julianus császár kijelentését akár bóknak is vehetnénk, jóllehet ő felháborodásának jeléül szánta, amikor a keresztényekre vonatkozóan odavetve megjegyzi: ezek nemcsak saját betegeiket, öregeiket, hanem a mieinket is gondozzák. Tertullianus és a Diognetoshoz irt levél már szállóigeként utal a keresztényekre használt korabeli kijelentésre: „Nézzétek, hogy szeretik egymást!”"11 Ez a „szállóige” Steven C. Muir a korai kereszténység karitatív tevékenységéről szóló írásának a címében is helyet kapott. ${ }^{12}$ A szerző hangsúlyozza, hogy a kereszténység egyrészt korán kidolgozta az irgalmas szeretet (elméleti) etikai tanításának az alapjait, másrészt kiépítette a kor színvonalához viszonyítva fejlett struktúráját a társadalom perifériájára szorultak, ideértve a fogyatékossággal élők gondozására. ${ }^{13} \mathrm{Ez}$ olyan „ideológiai” elem volt megfogalmazása szerint, amely bekerült és átjárta a vallás mindennapi gyakorlatát. ${ }^{14}$ A vallásfilozófusok rámutatnak a tagadhatatlan teológiai aspektusra, hogy a kereszténységben az elesettek segítése és az érte járó túlvilági jutalom korán összekapcsolódott. ${ }^{15} \mathrm{Ez}$ a szempont egyébként a Szentíráson kívüli úgynevezett apokrif munkák-

8 Leif E. Vaage: Ancient Religious Rivalries and the Struggle for Success: Christians, Jews, and Others in the Early Roman Empire. In Leif E. Vaage (szerk.): Religious Rivalries in the Early Roman Empire and the Rise of Christianity. (h. n.), Wilfrid Laurier University Press, 2006. 3-20.

9 Roger Beck: The Religion of the Mithras Cult in the Roman Empire. Oxford, Oxford University Press, 2006.

10 Maróth Miklós: A nesztorianizmus - elveszett keresztény közösség: tanulságok napjaink vallásközi párbeszédjéhez. Az előadás elhangzott a Keresztényüldözés a történelemben című konferencián 2019. április 11. Helyszín: NKE Hadtudományi és Honvédtisztképző Kar Zrínyi Miklós Laktanya és Egyetemi Campus, Díszterem.

11 Tertullianus: Apologe. 39,7.

12 Steven C. Muir: "Look How They Love One Another": Early Christian and Pagan Care for the Sick and Other Charity. In Leif E. Vaage (szerk.): Religious Rivalries in the Early Roman Empire and the Rise of Christianity. (h. n.), Wilfrid Laurier University Press, 2006. 213.

13 Muir (2006): i. m. 214.

14. Muir (2006): i. m. 218.

15 Justo González: Faith and Wealth: A History of Early Christian Ideas on the Origin, Significance, and Use of Money. San Francisco, Harper and Row, 1990. 75-78. Kifejezetten Máté Evangéliumában Jonathan T. Pennington: Heaven and Earth in the Gospel of Matthew. Leiden-Boston, Brill, 2007. 
ban, leginkább az apokaliptikákban is domináns szempont volt. ${ }^{16}$ A vallásfilozófusok mindennek leginkább a gyakorlati hasznosságára hívják fel a figyelmet. Ez nyilván nem elhanyagolható, amennyiben figyelembe vesszük, hogy a kereszténység milyen hatást gyakorolt a nyugati demokratikus társadalmak jogi és társadalmi berendezkedésére, az alapjogok, közte a fogyatékossággal élők esélyegyenlőségének megteremtésére. A segítés azonban sokkal inkább teológiai szempontra alapozódott. Csak ebből a megközelítésből világos, hogy a kereszténység nem csak programszerűen, hanem konstans módon a legkiszolgáltatottabbak szolgálatában áll. Luis Navarro rámutat, hogy az elesettek támogatása az egyház és az egyházi szervezetek munkájában nem pusztán filantróp szempontokra vezethető vissza, hanem az egyház lényegében keresendő. ${ }^{17} \mathrm{~A}$ keresztények számára az elesetekkel való törődést - szemben a legtöbb „pogány" római vallással - nem pusztán különböző praktikák és vallási tanok egyvelege, vagy azok többé kevésbé strukturált „rendszere” jelentette. A szegényekhez és a betegekhez való odafordulás csak az imitatio Christi tanból érthető. Ez nem is csak egyik tana a kereszténységnek, hanem annak conditio sine qua nonja. Röviden ez az alapító, a Názáreti Jézusnak a hívő által való legtökéletesebb követését jelentette. Ez a szemlélet az egyén szintjén túl átsugárzott az egyház egész struktúrájára. A protestáns egyháztörténész, Adolf von Harnack szerint már a 3. században megkülönböztethető a „karitász”, amelyet az egyén végez, és a „karitász, amelyet az egyház intézményes keretek között teljesít”." ${ }^{18}$ tökéletes Krisztus-követéshez szükséges lényegi elemeit magának az alapítónak az életét és tanítását bemutató Evangéliumokban foglalták össze. ${ }^{19} \mathrm{~A}$ keresztény ember az olvasott példák követésével akart még tökéletesebb kereszténnyé válni. A fogyatékkal élőkkel szembeni érzékeny európai eszme szempontjából óriási jelentőségü, hogy a teológia számára - ahogy XVI. Benedek pápa is fogalmaz - a hit Krisztusa és a történelem Jézusa egy és ugyanaz a személy. ${ }^{20} \mathrm{~A}$ vallástudomány megközelítése épp ellentétes: ${ }^{21}$ sőt, Rudolf Bultmann az Entmythologisierung, vagyis a mítosztalanítás gondolatának megalkotója óta, a vallásfilozófiai hermeneutika egyik alaptézisévé vált az a szemlélet, ${ }^{22}$ hogy Jézus személyének történelmileg hiteles feltárásához a szent szövegeket meg kell fosztani „misztikus jellegüktől”, leginkább a csodáktól. A katolikus teológia rámutat, hogy a csodaelbeszélésektől megfosztott evangéliumok éppen egy „torz Jézusképet” tárnának elénk. Eltekintve a kérdés krisz-

16 Kovacs Judith - Rowland Christopher: Revelation: The Apocalypse of Jesus Christ. Oxford, Blackwell Bible Commentaries, 2004.

17 Luis Navarro: Le iniziative dei fedeli nel servizio della carità. Fondamento e configurazione giuridica. In Jesús Miñambres (szerk.): Diritto canonico e Servizio della carità. Milano, Giuffrè, 2008. 196.

18 Adolf von Harnack: Mission und Ausbreitung des Christentums in den ersten drei Jahrhunderten. 4. Ed. Leipzig, (k. n.) [1902] 1924.

19 Paul N. Anderson - Felix Just - Tom Thatcher: John, Jesus, and History. Aspects of Historicity in the Fourth Gospel. Atlanta, Society of Biblical Literature, 2009.

20 XVI. Benedek: Názáreti Jézus. Budapest, Szent István Társulat, 2011.

21 Bruce J. Malina: The Social World Of Jesus and the Gospels. London - New York, Routledge, 1996.

22 Rudolf Bultmann: Glauben und Verstehen. Tübingen, J. C. B. Mohr, 1966; Rudolf Bultmann: Geschichte und Eschatologie. Tübingen, J. C. B. Mohr, 1964. Magyarázathoz lásd William O. Walker: Demythologizing and Christology. Forum, 3. (2014), 2. 35-45. 
tológiai vonatkozásától, a csodák elhagyásával az evangéliumok eszmetörténeti hatása is töredékessé válik. A krisztuskövetők a századok alatt a Jézus-karakter integráns részének tekintették, hogy „sántákat, vakokat, süketeket és más betegeket gyógyít”, és ebben „utánozni” akarták őt. A Jézus-történetet ugyanis tagadhatatlanul meghatározza a „csodás” gyógyítások sorozata. A Szentírás a történetek bemutatásánál tipizál ugyan, mivel a betegségeket nem orvosi szempontból írja körül, de nyilván a gyüjtőfogalmak alatt az összes fogyatékossággal élő személyt kell értenünk. Jézus általánosságban „bénákat” (Mt 9,1-8; 2,1-12; 5,17-26; Jn 5,1-18); „béna kezü” embert (Mt 12,9-13; Mk 3,1-6; Lk 6,6-11.), más helyeken „leprásokat” gyógyít (Mt 8,1-4; Mk 1,40-45; Lk 5,12-16; Lk 17,11-19). Ugyancsak tipikum a „vakok” (Mt 9,27-30; 20,29-34; Mk 8,22-26; 10,46-52; Lk 18,35-43; In 9), illetve a „süketnémák” gyógyítása (Mk 7,31-37). Egy helyen szerepel a „vízkóros” meggyógyítása szombaton (Lk 14,1-6). Más esetekben még általánosságban sem történik utalás a betegség típusára, csak a gyógyításra (például kafarnumi százados szolgájának gyógyítása [Mt 8,5-13; Lk 7,1-10, vagy a királyi tisztviselő fiának meggyógyítása Jn 4,46-54]). Ismét más esetekben a Szentírás szerzője még ennyire sem bocsátkozik részletekbe, csak kijelenti, hogy tömegek vagy legalábbis egy nagyobb csoport gyógyult meg (Mt 8,16; 11,4-5; 12,15-21; 14,34-36; 15,29-31; 19,1-2; 21,14; Mk 1,32-34; 3,7-12; 6,1-6; 6,53-56; Lk 4,40-4; 6,17-19; 7,21). A biblikus tudományokban - különösen az egzegézisben - óriási irodalma van a jézusi csodák magyarázatának. Ez esetben témánk szempontjából egyetlen, a Szentírásban is használt szófordulattal foglalnám össze a csodák eszmetörténeti jelentőségét. A leprás meggyógyításánál Jézus motivációját a szent szerző így summázza: „Jézusnak megesett rajta a szíve" (Mk 1,40-45). ${ }^{23}$ Ebben a mondatban csúcsosodik ki az összes gyógyítástörténet lényege. Mindemellett nemcsak arról van szó, hogy Jézusnak mint magányos „vándorprédikátornak” megesett a szíve a betegeken. Mivel a már említett Krisztus utánzása tan a tanítványság fokmérőjévé vált, kulcskérdése lesz a Krisztus-követésnek is, hogy az egyház tagjainak "megesik-e a szíve” a legkiszolgáltatottabbakon. ${ }^{24} \mathrm{~A}$ fogyatékossággal élők esetében pedig kétségtelenül ilyen emberekről van szó. Továbbá nemcsak Jézus példája, hanem szavai is motiválták később a keresztény közösséget. Keresztelő János tanítványainak kérdésére, hogy Jézus-e a messiás, Krisztus nem deklaratív igen-nem kijelentést tesz, hanem saját küldetésének lényegét, vagyis a legkiszolgáltatottabbak gyógyulásának (gyógyításának) elősegítését hirdeti: „Menjetek, s adjátok tudtul Jánosnak, amit hallotok és láttok: Vakok látnak, sánták járnak, leprások megtisztulnak, süketek hallanak, halottak feltámadnak, a szegényeknek pedig hirdetik az evangéliumot" (Mt 11,4-5.). A kijelentést a messiási kor apokaliptikus dimenziójában is értelmezték, amellyel a felsorolt társadalmi csoportok gyógyulása a messiási kor

23 „Abban az időben egy leprás jött Jézushoz. Térdre borult előtte, és így kérlelte: »Ha akarod, te megtisztíthatsz engem!« Jézusnak megesett rajta a szíve. Kinyújtotta kezét, megérintette, és azt mondta neki: »Akarom! Tisztulj meg!«"

24 Kempis Tamás Krisztus követése című, klasszikus spirituális könyvében is kitüntetett helyre helyezi a szegények gondozását. Kempis Tamás: Krisztus követése. Esztergom, Ecclesia, [1493], 1976. 19. 
jellemzőjének is tekinthető. ${ }^{25} \mathrm{~A}$ betegek segítése a nagy missziós parancshoz is kapcsolódott: „Menjetek és hirdessétek: közel van a mennyek országa! Betegeket gyógyítsatok meg, halottakat támasszatok fel, leprásokat tisztítsatok meg, ördögöket űzzetek ki! Ingyen kaptátok, ingyen is adjátok" (Mt 10,16).

\section{Jézus példájának és utasításának továbbélése: vagyis út a fogyatékossággal élők jogvédelme felé}

Bár a fentiekben említett bultmanni szemlélet szerint az ismertetett szentírási példák pusztán a jámbor prédikációk kategóriájába tartoznak, érdemes kiemelni ezen tanítások és magatartásformák társadalomformáló jelentőségét. A korszakváltás kezdetét mi sem szemlélteti jobban, mint az a különbség, amely a „leprások” ószövetségi megítélése és a velük való bánásmód, illetve a fent említett jézusi magatartás között megmutatkozik. Az Ószövetség egyik jelentős „jogi” gyüjteménye a Leviták könyve részletesen rendelkezik a leprásokkal való bánásmódról. Egész fejezeten keresztül részletezi a különböző bőrbetegségek megítélését és azok társadalmi következményeit. Jól summázza a könyv 14 . fejezete annak társadalmi hatását, ha a leviták súlyos bőrbetegséget (leprát) „diagnosztizáltak”.

„Akit a betegség megtámadott, szaggassa meg ruháját, a haját hordja kibontva, a szakállát takarja be és kiabáljon: »Tisztátalan, tisztátalan!« Ameddig a betegsége tart, addig tisztátalan, s mivel tisztátalan, lakjék elkülönülve, tartózkodjék a táboron kívül” (Lev 13,45).

Az ószövetségi részhez érdemes két megjegyzést füzni. Egyrészt, azzal, hogy a betegség végső minősítését a levitákra bízza az Ószövetség, egyben a kérdést a tiszta és tisztátalan dichotómiájába, vagyis a szakrális világba utalja. Innentől kezdve a lepra nemcsak egészségügyi kérdés, hanem a szakrális területen is megjelenik. A tiszta kedves Isten előtt, de a tisztátalan nem. Másrészt bár napjaink társadalmi értékrendje szerint megalázó következményekkel járt a leprássá és így tisztátalanná minősítés, a mérlegelésben szükséges tisztázni a korabeli közösségek önvédelmi mechanizmusát. A diszkriminatív ószövetségi eljárás vizsgálatakor figyelembe kell venni két, a kor társadalmait jellemző tényezőt. A környező népek sem álltak a betegek megítélésében erkölcsileg magasabb fokon. ${ }^{26} \mathrm{Az}$ „orvostudomány” alacsony fokon állt. A közösség általános higiénés minőségének fenntartásához szükségesnek bizonyult a fertőző „betegeket" távol tartani egészséges embertársaiktól. ${ }^{27}$ Mindamellett, még így is magya-

25 Nem véletlen, hogy a terület az apokrif apokaliptikus írásokban is eminens helyre került. A területet kiválóan feldolgozta Joseph Lumpkin. Lásd például Joseph B. Lumpkin: The Apocrypha: Including Books from the Ethiopic Bible. Blountsville, Fifth Estate Publishers, 2009a; Joseph B. Lumpkin: Lost Books of the Bible: The Great Rejected Texts. Blountsville, Fifth Estate Publishers, 2009b.

26 E. V. Hulse: The Nature of Biblical 'Leprosy' and the Use of Alternative Medical Terms in Modern Translations of the Bible. Palestine Exploration Quarterly, 107. (1975), 2. 87-105.

27 T. Wytton Davies: Bible Leprosy. The Old and New Testament Student, 11. (1890), 3. 142-152.

ACTA HUMANA • 2021/4. 
rázatra szorult, hogy miért kell így bánni ezekkel az emberekkel. Legegyszerübben az ember (vagy felmenői) által elkövetett bünre adott isteni büntetéssel igyekeztek feloldani a diszkriminatív intézkedéseket. Ennek a felfogásnak a késő zsidóságban való továbbélését nemcsak Jób könyve, hanem az újszövetségi hely is jól szemlélteti, ahol „egy születése óta vak ember” kapcsán megkérdezik Jézustól: „Mester, ki vétkezett: ez vagy a szülei, hogy vakon született?” (Jn 9,2). A tanítványok kérdésfeltevéseiből látszik, hogy az Ószövetség olvasatában minden súlyos emberi betegségre generálisan kiterjesztették azt a felfogást, miszerint az a személyes vagy generációs bünök miatt az Isten igazságos büntetéseként jelentkezik. Ahogy ez a felfogás évszázadokon keresztül uralta a társadalmi, „jogi” és szakrális életet, Jézus tanítványoknak adott válasza is kihat mindhárom területre. Jézus ugyanis lezárja a kérdést: „nem ő vétkezett, nem is a szülei" (Jn 9,2). A rövid, de jelentőségteljes kijelentés elvezet a második példánkhoz. A Life Explores magazin egész számot szentelt Jézus csodáinak, illetve, hogy azok hogyan változtatták meg a beteg és elesett emberekről való gondolkodásunkat. ${ }^{28}$ Rávilágít, hogy a kereszténységnek köszönhető, hogy nyugati világunkban idővel kialakult az a jogszabályi keret, amely védi és segíti a fogyatékkal élőket. A cikk jelentősége többek közt abban rejlik, hogy a lap nem egyházközeli, és vallásos attitüdökkel sem rendelkezik. Így különösen jelentős, hogy egy ilyen lap a kereszténység társadalomformáló erejére hívja fel a figyelmet. Minden szempontból kijelenthető, hogy a kereszténységgel valóban új időszámítás kezdődött mindazok számára, akik fogyatékossággal élnek. Mindennek azonban nemcsak társadalmi és jogi vetülete van. A személy, az individuum szempontjából is jelentős a jézusi tanítás és a keresztény praxis. A társadalmi reintegráció ugyanis kihat ezeknek a személyeknek az énképére és önértékelésére. Innentől kezdve már nem „tisztátalanok”, és „érinthetetlenek” a város falain kívül élő idegenek. Ahogy Szent II. János Pál az emberi élet sérthetetlenségéről szóló Evangelium Vitae kezdetű enciklikájában fogalmazott:

„[H]a elfogadjuk és szeretjük őket a bátorság és a derü, amellyel súlyosan fogyatékos testvéreink élik életüket, különösen hatékony tanúságot tesz azokról a hiteles értékekről, amelyek minősítik és nehéz körülmények között is drágává teszik az életet önmaguk és a környezetük számára is." ${ }^{29}$

\section{Az ókeresztény kortól napjainkig}

Ahogy azt már röviden említettük, Krisztus példájának és tanításának minél tökéletesebb elsajátítása és követése mint a keresztény ember célja korán megfogalmazódott az egyház tanításában. Az egyház születését elénk táró kánoni könyv, az Apostolok Cselekedetei is első csodaelbeszélésében egy bénán született ember meggyógyítását

28 Life (Explores): Jesus How His Lessons, Miracles and Devotion Changed the World. Life, 2019. december 6 .

29 II. János Pál: Enc., Evangelium Vitae. 1995. III. 25. 88. n. Acta Apostolicae Sedis, 87. (1995), 5. 500502. 
írja le. ${ }^{30} \mathrm{~A}$ történet ilyen eminens helyre állítása kiemelkedő jelentőségü. A lukácsi kettős mü - minthogy Lukács írta az egyik evangéliumot és az Apostolok Cselekedeteit is - azzal a sajátos teológia igénnyel íródott, hogy Jézus életét és az első keresztény (apostoli) közösség tevékenységét azok teológiai párhuzamában mutassa be. ${ }^{31} \mathrm{~A}$ mü szerzőjét az motiválta, hogy a mindenkori olvasó példát meríthessen annak felismeréséből, hogy Jézus élete és tanítása már az apostoli egyházat és konkrétan magukat az apostolokat is inspirálta. Ilyen értelemben kitüntetett jelentőségü, hogy az első csoda egy „bénán született ember” gyógyításáról, és ami talán ennél is fontosabb, ennek az embernek a templomi közösségbe, vagyis a zsidó népet egyébiránt jelképező templomba való reintegrációjáról szól. ${ }^{32}$ A történetből még egy ekkleziológiai (egyháztani) konklúziót is levonhatunk. Az Apostolok Cselekedetei a történetben nem véletlenül a két apostol: Péter és János tevékenységének tulajdonítja a csodát. Péter az apostol fejedelem. Példája napjainkig nagyban meghatározza és motiválja az egyház tagjait a fogyatékossággal élőkkel szembeni irgalmas szeretet megélésében. Szent Péter utódai pedig különösen fontos küldetésüknek tekintették, hogy Péter példáját a korszak társadalmi és szociális kihívásainak a fényében alkalmazzák a fogyatékossággal élők tekintetében. ${ }^{33} \mathrm{Ez}$ a legkülönbözőbb szinteken történhet. Teoretikus szempontból jelentősek az egész társadalmat érzékenyítő szociális enciklikák. Ezek kivétel nélkül érintik a fogyatékossággal élőkkel szembeni társadalmi és jogi kérdéseket. ${ }^{34} \mathrm{~A}$ történet

30 „Péter és János a kilencórai imádság idején fölment a templomba. Éppen akkor vittek oda egy bénán született embert, akit mindennap letettek a templom úgynevezett Ékes-kapujánál, hogy a templomba menőktől alamizsnát kérjen. Amikor meglátta Pétert és Jánost, amint épp be akartak menni a templomba, alamizsnáért könyörgött. Péter Jánossal együtt rátekintett, és így szólt hozzá: »Nézz ránk!« Erre rájuk emelte tekintetét, abban a reményben, hogy kap tőlük valamit. Péter azonban ezt mondta neki: »Aranyom, ezüstöm nincs, de amim van, neked adom: A názáreti Jézus Krisztus nevében (állj fel és) járj!« Jobb kezénél fogva fölsegítette, mire annak nyomban erő szállt a lábába és a bokájába" (Ap.Csel 3,1-7).

31 A két mủ társadalomfilozófiájáról és a szerzői motivációkról átfogó monográfia. Alexander Loveday: The Preface to Luke's Gospel Literary Convention and Social Context in Luke 1.1-4 and Acts 1.1. Cambridge, Cambridge University Press, 1993.

32 A templom jelentőségéhez és ilyen jellegű funkcióihoz lásd Timothy Wardle: The Jerusalem Temple and Early Christian Identity. Tübingen, Mohr Siebeck, 2010.

33 Wilhelm Levison: Zur Vorgeschichte der Bezeichnung Servus servorum Dei. Zeitschrift der Savigny-Stiftung für Rechtsgeschichte. Kanonistische Abteilung, 6. (1916), 1. 384-386.

34 XIII. Leó: Enc. Rerum novarum. 1891. V. 15. Acta Sanctae Sedis, 23. (1891), 641-670; XI. Pius: Enc. Quadragesimo anno. 1931. V. 15. Acta Apostolicae Sedis, 23. (1931), 6. 177-285; XXIII. János: Enc. Mater et magistra 1961. V. 15, Acta Apostolicae Sedis, 53. (1961), 401-464; VI. Pál: Enc. Populorum progressio 1967. III. 26. Acta Apostolicae Sedis, 59. (1967), 257-299; VI. Pál: Octogesima adveniens. 1971. V. 14. Acta Apostolicae Sedis, 63. (1971), 8. 401-444; II. János Pál: Enc. Laborem exercens. 1981. IX. 14. Acta Apostolicae Sedis, 73. (1981), 9. 577-647; II. János Pál: Sollicitudo rei socialis 1987. XII. 30. 80. (1988), 5. 513-586; II. János Pál: Centesimus annus. 1991. V. 1. Acta Apostolicae Sedis, 83. (1991), 10. 793-867; XVI. Benedek: Enc. Deus Caritas est. 2005. XII. 22. Acta Apostolicae Sedis, 98. (2006), 3. 217-279; XVI. Benedek: Litt. Ap. MP. Intima Ecclesiae natura. 2012. XI. 11. Acta Apostolicae Sedis, 104. (2012), 12. 996-1004. Ehhez összefoglaló munka: Bernard A. Hebda: Where Canon Law Connects with Caritas: The Norms of Intima Ecclesiae Natura. A Year of Mercy Examination of Challenges to Compliance in a US Context. The Jurist, 76. (2016), 2. 339-359. 
másik szereplője János. János a szeretett tanítvány, akinek karizmatikus lelkesedése már az ókeresztény egyházat az irgalmas szeretet tetteire, így a fogyatékossággal élők szeretetére inspirálta.

Az „eszmény” elmélyítésében később kulcsszerepet játszottak a korai egyházatyák. Nagy szerepet játszottak abban, hogy a szegénygondozás és azon belül a fogyatékossággal élők segítése az elméleti teológia integráns része lett. Szinte kivétel nélkül írtak az elesettekről való gondoskodás különböző szempontjairól. Példálózó jelleggel említhetjük Kelemen első levélét (54.4; 55.2); Szent Jusztiniánusz Apologetikáját (1 Apol. 1.67); a Diognétoszhoz írt levelet (10.6); Hermász pásztorát (1.5, 8-9; 3.7); Tertullianus (Apol. 39.5-6, 16; 42.8), Alexandriai Kelemen (Quis div.) Lactantius, (Div. Inst. 6.12.) vagy Kaiszareiai Euszebiosz munkáit (Eusebius, Hist. eccl. 9.8.). A kérdés teoretikus/teológiai mélyítése és a gyakorlat már az ősegyházban egymással szoros kölcsönhatásban állt. Ehhez járult sajátosan hozzá a szentek kultikus tisztelete. Már az első keresztény századokban is, amikor még a vértanúk tanúságában látták leginkább a Krisztus utánzásának legeminensebb megjelenését, ${ }^{35}$ a korszakos szentek karakterábrázolásánál helyet kapott a „fogyatékossággal élők” segítése is. Elég a Magyarországon is nagy tiszteletnek örvendő katona, illetve püspök és szerzetes, Szent Márton élettörténetének ominózus jelenetét feleleveníteni, ${ }^{36}$ amikor megosztja a köpenyét a koldussal. Bár a legtöbb forrás csak a koldus karaktert említi, a művészeti ábrázolások több esetben sejtetnek mozgásszervi rendellenességre utaló jegyeket is. E szentek későbbi „hírnevének” elmélyítéséhez jelentősen hozzájárultak a már említett teológus egyházatyák. Homíliáikban gyakran tértek ki a szent karitatív tevékenységére is. Szent Ambrus például így beszél Szent Mártonról: „[F]eltámasztotta a halottakat, megszállottak testéből kiűzte a gonosz démonokat, az üdvösség orvosságával gyógyította a sokféle betegségben kínlódókat." ${ }^{37}$

Tendencia volt később is, hogy a fogyatékossággal élők segítését olyan esetekben is hangsúlyozták a szentek életrajza kapcsán, amikor egyébként az adott szent életútja az egyház szolgálatának más dimenziójában csúcsosodott ki. A későbbiekben ez a szempont meg is erősödött, minthogy a vértanú szentek korszaka (egy-két missziós régiót leszámítva) a 4. századtól a társadalmi átalakulások miatt már nem volt meghatározó. Így Krisztus utánzásában egyre dominánsabb szerepet kapott a legkiszolgáltatottabbak, köztük a fogyatékossággal élők támogatása. Jól szemlélteti az „irgalmas” Krisztus képének felelevenítését az ismert szentek karakterábrázolása. Életrajzukban kitüntetett helyen szerepeltek azok a jelenetek, amikor "leprásokat”, „bénákat” segítettek (például Assisi Szent Ferenc; Szent Erzsébet). Nem elhanyagolható, hogy ezek a társadalmat kétségtelenül érzékenyítő momentumok széles körben

35 Maarten Taveirne: Das Martyrium als imitatio Christi: Die literarische Gestaltung der spätantiken Märtyrerakten und -passionen nach der Passion Christ. Zeitschrift für Antikes Christentum/Journal of Ancient Christianity, 18. (2014), 2. 167-203.

36 Ujházi Lóránd - Kliszek Németh Noémi: A szerzetestől és püspöktől a katonáig, avagy a Szent Márton kultusz formálódása. Felderitố Szemle, 15. (2016), 4. 32-41.

37 Jacobus De Voragine: Legenda aurea. Budapest, Neumann Kht., 2004. 
megjelentek a keresztény képzőművészetekben. Christine M. Boeckl egész monográfiában mutat rá, hogyan ábrázolták a keresztény művészetekben, közte a szentek ikonográfiájában a leprások segítését. ${ }^{38}$ Messze nem a teljesség igényével, hanem Boeckl munkájából szemezgetve emelnénk ki egy-egy, a témánk szempontjából szemléltető példát. İgy a középkori egyházi élet túlzás nélkül egyik legmeghatározóbb személyiségét, a rendalapító Assisi Szent Ferencet. Életének egyes markáns jeleneteit előszeretettel örökítették meg a keresztény művészetben. Tekintve, hogy a ferences rend milyen méreteket öltött már kevéssel az alapító halála után, ezek az alkotások Európa-szerte megjelentek. Boeckl kiemeli például Hertul mester magyar képes legendáriumát, ahol Assisi Szent Ferenc lehajol egyesek szerint egy lepráshoz, mások szerint egy béna emberhez. ${ }^{39} \mathrm{~A}$ művész úgy ábrázolta a jelenetet, hogy abból felismerhetővé váljon az utolsó vacsora gesztusa, ahol maga Jézus hajol oda, hogy megmossa a tanítványainak a lábát, miközben utasítást ad a karitász tetteinek a végrehajtására: „Példát adtam, hogy amit én tettem, ti is tegyétek meg” (Jn, 13,15). A társadalom érzékenyítése szempontjából talán még fontosabb, hogy számos uralkodó és a középkori társadalmak életét meghatározó nemesek úgy jelentek meg a köztudatban, mint akik leprások, bénák és egyéb testi fogyatékossággal élők patrónusai. (Lásd például magyarországi vagy türingiai Szent Erzsébet [1207-1231], francia IX. Lajos [1214-1270], Benizzi Fülöp [1233-1285]). A teljesség igénye nélkül utaljunk a magyar vonatkozású Árpád-házi Szent Erzsébetre. A szent a legsúlyosabb betegségekben szenvedők iránti heroikus áldozatvállalását a katolikus jámbor irodalom permanensen állította a keresztény hívek elé. Domenico Maria Manni a barokk korban így ír Szent Erzsébetről:

„[L]átogatta a betegeket és a leprásokat, s felöltöztette őket, olyannyira, hogy nemegyszer nem maradt más ruhája, amelyet magára ölthetett volna, csupán egy alantas, szegényekhez illő szoknyácska. Egészen haláláig, miután megözvegyült és apácává lett, mindvégig igen vágyott arra, hogy a szegényeket, betegeket és leprásokat szolgálja és támogassa. Személyesen is szolgálta, átöltöztette és mosdatta őket: néha előfordult, hogy egy éjszaka hatszor vitt el az árnyékszékre egy beteget." ${ }^{40}$

Bár felmerülhet a kérdés a jámbor irodalom és legendáriumok történelmi hitelességéről, de témánk szempontjából ez nem fontos ${ }^{41}$ Számunkra az a jelentős, hogy a katolikus nemesség és az uralkodók fogyatékossággal élőkkel való törődésének bemutatása társadalomérzékenyítő hatású volt.

38 Christine M. Boeckl: Images of Leprosy Disease, Religion, and Politics in European Art. Kirksville, Missouri, Truman State University Press, 2011. Különösen a 4., 5., 6. fejezet.

39 Boeckl (2011): i. m. 84.

40 Vita di Santa Elisabetta. In Domenico Maria Manni (szerk.): Vite di alcuni Santi. Firenze, 1735. 705-726. Magyar forrás: www.insegnanet.elte.hu/articoli/arpad-hazi_szent_erzsebet.htm

41 Átfogó elemzéshez lásd Szűcs Kata: A Szent Erzsébet-kultusz Magyarországon és Portugáliában. In Adsumus XII. Tanulmányok a XIV. Eötvös Konferencia elöadásaiból. Budapest, Eötvös Collegium, 2014. 115-135. 
Érdemes néhány szót szólni a fogyatékossággal élők segítésének intézményes oldaláról. A már említett Apostolok Cselekedeteiben megtaláljuk a halvány jeleit annak, hogy a közösség elmozdul az irgalmasság cselekedeteinek egyéni szintjéről a közösségi felelősségvállalás irányába. Az apostolok kiválasztják a hét diakónust „a szegények gondozására” (Ap.Csel 6,2-3, 5-6). Így nem túlzás azt állítani, hogy az első „hivatalok” ${ }^{42}$ kifejezetten az elesettek gondozására jöttek létre. ${ }^{43}$ Kevéssel a konstantini kor előtti időszakból ismert az úgynevezett „parabolani” közösség. Feltehetően a nagy pestisjárványok időszakában jött létre, és saját küldetését a betegek gondozásában jelölte meg. A későbbi szerzetesrendeket jellemző fogadalmakat még nem tettek, ahogy különösebb szabályzattal sem rendelkeztek. John A. Knight a megszentelt életről írt könyvében rámutat, hogy a csoport neve is beszédes. A paraboleüszamenosz szó jelentése kockáztató. A kifejezést, amelyet eredetileg a szerencsejátékosokkal kapcsolatban használtak, szándékosan alkalmazták a betegápolók saját magukra is, mintegy kifejezve, hogy életüket a legelesettebbek szolgálatának szentelik. ${ }^{44} \mathrm{~A}$ jusztiniánuszi korban a csoportról már nem emlékeznek meg a források. A betegápolás intézményes keretét ugyanis fokozatosan a betegápoló szerzetesrendek vették át. Történelmi távlatban sem egyházi, sem világi viszonylatban nem találunk olyan csoportokat, amelyek többet tettek volna a fogyatékossággal élők érdekében. Krutsay Miklós általánosságban így foglalja össze ezeknek a szerzetesrendeknek a küldetését: „[...] süketnémák nevelését, fogyatékosok gondozását vállalják". ${ }^{45}$ A legismertebb betegápoló rendek közé soroljuk a Remete Szt. Antal Ispotályos Rendet, Keresztelő Szent Jánosról nevezett Jeruzsálemi Szuverén Katonai és Kórházi Lovagrendet; a Szent Lázár Katonai és Kórházi Lovagrendet, a jezsuitákat, az irgalmasrendieket és a kamilliánusokat. Az egyes rendekről is számos rendtörténeti, illetve jelenlegi tevékenységüket ismertető munka jelent meg, amelyek megható képet festenek az egyes rendek áldozatos munkájáról. A betegápoló rendekről általában pedig Anna Esposito és Andreas Rehberg jelentetett meg átfogó kötetet. ${ }^{46}$ Talán a történelmi tények hideg logika szerinti felsorolásánál jobban érzékelteti ezeknek a szerzetesrendeknek társadalomformáló erejét Krutsay doktor összefoglalója. Mint orvos nemcsak a történeti aspektusra mutat rá, hanem azokra a korszakos betegségekre is, amelyek okát sem felismerni nem tudták, sem ebből kifolyólag gyógyítani. A betegápoló rendek pedig ilyen, emberi szempontból reménytelen helyzetekben is a betegek mellett álltak. A Krutsay által vizsgált

42 Jesús Miñambres: Considerazioni sulla provvista di uffici ecclesiastici per presentazione premessa nel codice del 1983. Ius Ecclesiae, 11. (1999), 407-418.

43 Lóránd Ujházi: The Significance of Charity (Caritas) in the Governing, Sanctifying, and Teaching Mission of the Church. Bogoslovni Vestnik, 80. (2020), 4. 783-802.

44 John A. Knight: The Holiness Pilgrimage. Kansas City, Beacon Hill, 1986. 19-20.

45 Krutsay Miklós: Betegápoló szerzetesrendek. Osteologiai Közlemények, 26. (2018), 1-2. 52-54.

46 Anna Esposito - Andreas Rehberg: Gli ordini ospedalieri tra centro e periferia. Roma, Ricerche dell'Istituto Storico Germanico di Roma, 2007. Magyar vonatkozásokhoz Falus Orsolya: Ispotályos keresztes lovagrendek az Árpád-kori Magyarországon. Doktori (PhD-) értekezés. Pécs, Pécsi Tudományegyetem Állam- és Jogtudományi Kar, 2014. 
betegségek közül példaként említhető a Claviceps purpurea mérgezés ergotizmus, amelyet a megfertőzött gabonafélék okoztak: „kezek és a lábak elhaltak, megfeketedtek és mumifikálódva letörtek". ${ }^{47} \mathrm{Ez}$ önmagában szemlélteti a betegápoló rendek elkötelezettségét. Végül érdemes utalni arra is, hogy más szerzetesrendek is voltak, amelyek bár más karizmával rendelkeztek, de időnként felvállalták a fogyatékossággal élők ügyét.

\section{A fogyatékossággal élők segítése a katolikus egyházban}

Magyarország Alaptörvénye nemzeti hitvallás részében elismeri a kereszténységnek a nemzeti történelemben betöltött meghatározó szerepét. A Szabadság és felelősség rész alatt pedig kiemeli, hogy az „állam és a vallási közösségek a közösségi célok elérése érdekében együttműködhetnek" (VII. cikk). Kevés nemesebb és egyben konkrétabb együttműködés van a két entitás között, mint a fogyatékossággal élők ügyének előmozdítása, legyen az akár a társadalom érzékenyítése vagy konkrét tevékenység. ${ }^{48} \mathrm{~A}$ történelmi példákból láttuk, hogy az egyház akkor is szívén viselte a „fogyatékossággal élők” ügyét, amikor az állam még nem fordított (kellő) figyelmet ezekre az emberekre. A társadalmi átalakulások, a jogállami és a demokratikus szempontok artikulációjának következtében a 20. századra a nemzetközi és állami jogalkotás, végrehajtás és szociális gondoskodás is jelentős figyelmet szentelt a fogyatékossággal élőknek. Ezzel az egyház és szervezetei már nem „hiánypótló” szerepet töltenek be, hanem az Alaptörvény szavainak megfelelően az állammal egymást támogató funkciójuk van. ${ }^{49}$ Napjaink katolikus egyházának tevékenysége kapcsán számos disztinkciót kell azonban tenni. Mind az egyetemes egyház, mind a részegyházak szintjén beszélhetünk ugyanis a fogyatékossággal élők ügyének formális és informális eszközökkel való előmozdításáról. ${ }^{50} \mathrm{Az}$ utóbbihoz tartoznak az egyetemes egyház szintjén az évenként visszatérő, fogyatékossággal élők világnapján elhangzó érzékenyítő beszédek, vagy más alkalommal történő pápai megnyilatkozások. ${ }^{51}$ A 20. század második felének pápái számos alkalommal fejezték ki legmélyebb együttérzésüket a fogyatékossággal élők irányába, illetve igyekeztek a társadalmat érzékenyíteni. Ebből fakadóan lehetetlen kimerítő listáját adni ezeknek a megnyilatkozásoknak. Ugyanakkor éppen a számosság jelzi, milyen fontos helyet foglaltak

47 Krutsay (2018): i. m. 52.

48 Schanda Balázs: Magyarország keresztény kultúrájáról. Pázmány Law Working Papers 2018/08. Budapest, Pázmány Péter Katolikus Egyetem, 2018. Lásd még Schweitzer Gábor: Becsüljük országunk különböző vallási hagyományait. In Patyi András (szerk.): Rendhagyó kommentár egy rendhagyó preambulumról - Magyarország Alaptörvénye, Nemzeti hitvallás. Budapest, Dialóg Campus, 2019. 107-121.

49 Zsákai Róbert - Horváth László: Az Egyház és a társadalom kapcsolata. Hadmérnök, 8. (2013), 4. 265-271.

50 Barbara Rozen - Maksym Adam Kopiec: Le persone disabili nell'economia della salvezza di Dio. Forum Teologiczne, 20. (2019). 109-125.

51 Anne Masters: An Opportunity for Charity? A Catholic Tradition in Understanding Disability and its Impact on Ministry. Journal of Disability E Religion, 20. (2016), 3. 218-227. 
el a 20. századi pápák társadalomképében a fogyatékossággal élők. Müfaji sajátosság miatt kitüntetett helyen szerepelnek az enciklikák, amelyek sokoldalúan közelítenek a fogyatékossággal élők kérdéséhez. XI. Pius Casti Connubii kezdetű enciklikája például a házasság, illetve az állam büntető hatalma kapcsán veszi védelmébe a fogyatékossággal élőket. ${ }^{52}$ II. János Pál Redemptoris missio kezdetű enciklikájában pedig a világmisszió, kitüntetett címzettjeinek tekinti őket. ${ }^{53}$ XVI. Benedek Sacramentum caritatis kezdetű szinódus utáni apostoli buzdítása pedig a szentségkiszolgáltatás kapcsán fogalmazza meg, hogy mind a szellemi, mind a testi fogyatékossággal élők számára a lehető legtágabb lehetőséget kell biztosítani ahhoz, hogy a szentségekben részesülhessenek. A buzdítás a teológiai magaslatokból „leereszkedve” konkrét praktikus tanácsokat is megfogalmaz, minthogy

„különös figyelmet érdemelnek a fogyatékosok; amennyiben állapotuk ezt megengedi, a keresztény közösségnek segítenie kell, hogy a kultusz helyén vehessenek részt az ünneplésben. Gondoskodni kell arról, hogy a szakrális épületekből eltávolítsák az esetleges építészeti akadályokat, melyek lehetetlenné teszik a fogyatékosok bejutását".54

Ferenc pápa szociális érzékenysége megválasztása óta nyilvánvaló volt. A fogyatékossággal élők támogatása és segítése jól illeszkedik a pápa szociális víziójába, amely az elesettek, a menekültek, egyéb okból a társadalom perifériájára került személyek méltányos felkarolását jeleníti meg. Az Amoris laetitia kezdetű enciklikájában a család vonatkozásában deklarálja, hogy a „fogyatékossággal élő személyekre fordított figyelem a Lélek jele".55 A legújabb, Mindnyájan testvérek kezdetű enciklikájában pedig a jelenkori fegyveres konfliktusok homlokterébe helyezi a pápa a fogyatékossággal élők védelmét. Kijelenti, hogy szükséges az „élet szent mivoltának” tiszteletben tartása, manapság ugyanis „az emberiség bizonyos részei látszólag feláldozhatók”, mint a születendők, a szegények, a fogyatékossággal élők, az idősek". ${ }^{56}$ Ferenc pápa nem marad csak a szavaknál. Igyekszik a Római Kúria intézményeit is úgy pozícionálni, hogy érzékelhetővé váljon mindez az elköteleződés. Ferenc pápa 2016. augusztus 31-én kihirdetett Humanam progressionem kezdetủ motu proprioval ${ }^{57}$ új szentszéki hivatalt hozott létre: „Dikasztérium az Átfogó Emberi Fejlődés Szolgálatában”. ${ }^{8}$ Az új dikasztérium négy szentszéki hivatalt, a Iustitia et Pax, a Cor Unum, az Egészségügyi Dolgozók és az Elvándorlók és Úton Lévők Lelkigondozására létrehozott pápai ta-

52 XI. Pius: Enc. Casti Connubii, n. 2. 1930. XII. 31, 2. Acta Apostolicae Sedis, 22. (1930), 12. 539-592.

53 II. János Pál: Enc. Redemptoris missio. n. 60. 1990. XII. 7, Acta Apostolicae Sedis, 89. (1990), 308.

54 XVI. Benedek: Esort. Post. Synod. Sacramentum caritatis. n. 58. 2007. II. 22, Acta Apostolicae Sedis, 99. (2007), 3. 150.

55 Ferenc pápa: Amoris Laetitia. Budapest, Szent István Társulat, 2016. 19.

56 Ferenc pápa: Fratelli Tutti. Vatican, 2020. október 3.

57 Ferenc pápa: Motu proprio Humanam progressionem. Vatican News, 2016. augusztus 17.

58 Ujházi Lóránd: A szentszéki strukturális és jogszabályi módosítások az európai migrációs válság fényében. Acta Humana - Emberi Jogi Közlemények, 5. (2017), 2. 19-41. 
nácsokat integrálta. A dikasztérium felállítását elrendelő motu proprio röviden öszszefoglalja az új hivatal feladatát. Külön említésre kerülnek a veszélyeztetett társadalmi csoportok, többek között „a szükséget szenvedők, a betegek és a kirekesztettek.” Mindez nem azt jelenti, hogy ne lett volna a pápai intézkedés előtt olyan szentszéki hivatal, amely felkarolta volna a fogyatékossággal élők ügyét. Olyan szentszéki hivatal azonban tényleg nem volt, amely az ernyőszervezet szerepét töltötte volna be a veszélyeztetett csoportok védelmében. Másrészt a pápa szándéka nemcsak strukturális, hanem koncepcióbeli, minthogy a Római Kúria csúcsszerveként nem egy teoretikus kérdésekkel foglalkozó, hanem a legelesettebbeket segítő dikasztériumot akar látni. ${ }^{59}$ Ami a helyi egyházi kezdeményezéseket illeti, mind a püspöki konferenciák, mind a részegyházak számos fórumon nyilatkoznak, és részt vesznek a társadalom érzékenyítésében. ${ }^{60}$ Emellett a helyi egyházaknak mind karitatív, mind lelkipásztori kezdeményezéseik is vannak. Ami az utóbbit illeti, különösen jelentős a fogyatékossággal élők számára tartott katekézisek és a szentségkiszolgáltatásra való felkészítés. A számosság okán lehetetlen minden kezdeményezést és megnyilatkozást felsorolni. Éppen csak az érdekesség kedvéért álljon elöttünk Michel Aupetit, Párizs érsekének a példája, aki eredetileg maga is orvosként dolgozott. 2019 szeptemberében új helynökséget hozott létre azzal a céllal, hogy a fogyatékossággal élők könnyebben bekapcsolódhassanak a plébániák életébe. Munkacsoportjukban maguk a fogyatékossággal élők is részt vesznek, és az a céljuk, hogy a plébániákat érzékenyítsék. ${ }^{61}$

Végezetül meg kell jegyezni, hogy bármennyire is közös platformon áll a demokratikus jogállam, a nemzetközi szervezetek és a katolikus egyház a fogyatékossággal élők védelme érdekében, vannak területek, ahol a katolikus koncepció eltérést mutat. A katolikus egyház ugyanis a fogyatékossággal élők védelmét még átfogóbban értelmezi, mint a mainstream állami és nemzetközi (jogi) irodalom és az azt követő gyakorlat. A katolikus doktrína ugyanis elfogadhatatlannak tartja a magzati élet megszakítását pusztán azért, mert fejlődési rendellenesség vagy fogyatékossággal való születés veszélye áll fenn. ${ }^{62}$ Ebből kifolyólag a Szentszék számos olyan

59 Filippo Iannone: Curia Romana Semper Reformanda Le riforme postconciliari. Asprenas, 67. (2020), 1. 5-27.

60 Erdő Péter: A püspöki kar szerepe a modern államban. Vigília, 63. (1998), 1. 2-8.

61 Magyar Kurír: Párizs orvos végzettségü érseke a fogyatékossággal élők integrációjáért küzd (2020. január 12.).

62 Több pápai dokumentumban is megfogalmazást nyert. Legmarkánsabban: „A magzati vizsgálatok melyek erkölcsileg kifogástalanok, ha a magzat számára szükséges gyógyító beavatkozás céljával történnek - gyakran teremtenek alkalmat az abortusz javaslására és végrehajtására. Ez az eugenetikus (fajnemesítő) abortusz, melynek törvényesítése a közvéleményben olyan - a gyógyítás igényéhez tévesen kapcsolódó - lelkületből fakad, amely az életet csak bizonyos feltételekkel fogadja el, és elutasítja, ha sérült, fogyatékos vagy beteg." II. János Pál (1995): i. m. 416. Ferenc pápa pedig egy családszövetségnek tartott beszédében:

„Hallottam, hogy divatos, vagy legalábbis megszokott, hogy amikor a várandósság első néhány hónapjában vizsgálatokat végeznek, hogy lássák, a gyermek egészséges-e, vagy van-e valamije, az első ajánlat: szabaduljunk meg tőle [...] a gyermekek meggyilkolása... hogy könnyü életünk legyen, megszabadulunk egy ártatlantól [...] Fájdalommal mondom. A múlt században az egész világot megrázta, amit a nácik tettek a faj nemesítéséért. Ma is ugyanezt tesszük, csak fehér kesztyűkkel. 
nemzetközi dokumentumot sem írt alá, amelyek a katolikus álláspontnál szűkebben értelmezik a fogyatékossággal élők védelmét, és a védelmet a magzati életre nem terjesztik ki. ${ }^{63}$

\section{5. Áthajlások a kánoni és a világi jogrendszer között a fogyatékossággal élők támogatása kapcsán}

A szoros értelemben vett kánonjogi rendszer nem foglalkozik a fogyatékossággal élők esélyegyenlőségét biztosító konkrét kérdésekkel. Az egyház már tárgyalt általános teológiai és társadalmi elvei azonban értelemszerüen átsugároznak a szigorú értelemben vett kánonjogi előírások alkalmazására is. Tipikusan ilyen, amikor az egyház igyekszik a fogyatékossággal élők számára a lehető legszélesebb lehetőséget biztosítani az egyház életébe való bekapcsolódásra. Ezen túl az 1983-as Egyházi Törvénykönyv ismeri az úgynevezett kanonizáció intézményét. Ez a világi törvények átvétele a kánonjogba, azok teljes joghatásának megtartásával. ${ }^{64} \mathrm{~A}$ jogintézményt az a logikus szempont motiválta, hogy számos olyan terület létezhet, amely társadalmi jelentősége miatt érinti ugyan az egyházat is, de átfogó jogi szabályozását a dolog természete miatt inkább az állami szerv végzi. A kanonizációnak alávetett kérdéseket taxatíve felsorolták a hatályos joganyagban. A fogyatékossággal élőkre vonatkozó szabályok nem tartoznak ide. Ez nem jelenti, hogy a későbbiekben ne kerülhetne be a terület a kanonizált kérdések közé. Jelenleg azonban inkább a II. vatikáni zsinat által hangsúlyozott általános rendelkezés a domináns szempont: A Christus dominus kezdetủ határozat a püspöki szolgálatról felszólítja a püspököket, hogy segítsék elő a Krisztus-hívők között az igazságos világi törvények betartását. ${ }^{65} \mathrm{~A}$ fogyatékossággal élők jogait és esélyeit előmozdító világi jogi rendelkezések nyilván ebbe „az igazságos világi törvények kategóriába tartoznak". Továbbá lehetnek olyan ágazati elöírások is, amelyeket az egyház közjogi státusza és szerepvállalása miatt be kell tartani. Ez esetben azonban a jogot nem az egyház belső jogalkotója keletkezteti. Az egyház említett közjogi helyzete és vállalt társadalmi és ágazati feladatai miatt meg kell tartania az állami jogszabályokat és/vagy az ország nemzetközi kötelezettségvállalása-

Ez erőszak, de mi is ugyanezt tesszük." Ferenc pápa: Az abortusz a gyermekek meggyilkolása. Magnificat, 2018. június 19.

Más alkalommal: „[E]gy emberi lény sosem lehet összeegyeztethetetlen az élettel [...] azok a gyermekek is megérdemlik az egészségügyi ellátást az anyaméhben, akik várhatóan nem vagy csak kevéssel élik túl a születést."

63 Holy See cannot Join Convention on Disabled People. Cirkev, 2007. február 1.

64 Giuseppe Dalla Torre: La città sul monte. Contributo ad una teoria canonistica sulle relazioni tra Chiesa e comunità politica. Roma, AVE, 1996. 19-21. Lásd még Matjaž Muršič Klenar: Možnosti dialoga v sodobni sekularni družbi. Abstract Possibilities of Dialogue in the Modern Secular Society. Bogoslovni Vestnik, 80. (2020), 3. 575-584.

65 „A fölszentelt pásztorok nyájuk lelki gondozásán munkálkodva valójában a társadalmi és polgári haladásért és jólétért is fáradoznak; e célból tisztségük természete szerint, és ahogy püspökökhöz illik, az állami hatóságokkal tevékenyen együttműködnek, és az igazságos törvények iránt engedelmességre, a jogszerủen fönnálló hatóság iránt tiszteletre intenek" (CD 19). 
it. Ez minden olyan ágazati jogszabályt érint, amelyekre a fogyatékossággal élőkkel kapcsolatos szakpolitika átsugárzik, és az egyház pedig intézményei okán érintett. Tipikusan ilyen az egyházi infrastruktúra építésénél az akadálymentesítés. ${ }^{66}$ Vagy az 1998. évi a fogyatékos személyek jogairól és esélyegyenlőségük biztosításáról szóló XXVI. törvény (4. \$), amely a rehabilitáció kapcsán számos olyan „rendszert” érint (egészségügyi, mentálhigiénés, oktatási, képzési, átképzési, foglalkoztatási, szociális), amelyben az egyházi jogi személy által fenntartott, közfinanszírozásban részesülő intézmények jelentős szerepet vállalnak. Az ilyen intézmények működésére vonatkozóan a fent említett világi jogszabályok, állami hatóságok felé való elszámolása, illetve az állami hatóságok ellenőrzési joga és kötelezettsége evidencia. A kérdést azonban az állam oldaláról is megközelíthetjük: milyen kötelezettségei vannak az állami félnek, hogy a fogyatékossággal élők is minél jobban bekapcsolódhassanak az egyház életébe. A szólásszabadság és a véleménynyilvánítás anyajogából levezethető a lelkiismereti és a vallásszabadság szelvényjogának biztosítása az állam kötelezettsége. ${ }^{67}$ Jogos elvárás, hogy a fogyatékossággal élők esetében az állam még inkább figyeljen oda az alapjogok biztosítására, hiszen ezek a személyek sok esetben kiszolgáltatottabbak, ami a joggal való élést illeti. Erre számos olyan nemzetközi emberi jogi okmány is rámutat, amelynek Magyarország is részese. Így az ENSZ 1994-es Fogyatékossággal élő emberek esélyegyenlőségek alapvető szabályai. A dokumentum 12. pontja bátorítja a tagállamokat, hogy segítsék azokat az intézkedéseket, amelyek célja, hogy a fogyatékos emberek egyenlően vehessenek részt közösségük vallási életében. Továbbá kéri a tagállamokat, hogy az egyházi hatóságokkal „konzultálva támogassanak olyan intézkedéseket, amelyek megszüntetik a megkülönböztetést, és a vallási tevékenységet hozzáférhetővé teszik a fogyatékossággal élők számára”. A dokumentum szorgalmazza, hogy a fogyatékosságról szóló információs anyagok jussanak el az egyházi intézményekhez és szervezetekhez, illetve a tagállamok ösztönözzék az egyházi hatóságokat, hogy a fogyatékossági politikáról szóló információ a vallási hivatásokra való felkészítés és a vallási oktatási programok részét képezze. Végül pedig bátorítsák a tagállamok hatóságai, hogy a vallásos irodalmat tegyék hozzáférhetővé az érzékszervi károsodást szenvedett személyek számára is. A tagállamok pedig, illetve az egyházi szervezetek konzultáljanak a fogyatékossággal élők szervezeteivel, amikor intézkedéseket hoznak. ${ }^{68}$ Külföldi, főleg amerikai mintára

66 Az épített környezet alakításáról és védelméről szóló 1997. évi LXXVIII. törvény 2. \. kifejezetten a templomok akadálymentesítéséről tesz említést. Az Egyenlő Bánásmód Hatóság Tanácsadó Testület 384/1/2008. (I. 23.) TT. sz. állásfoglalása az akadálymentesítési kötelezettségröl. Lásd még Magyar Civil Caucus: Fogyatékos személyek jogai vagy fogyatékos jogok? Budapest, SINOSZ - MDAC - FESZT, 2010. 120.

67 Általánosságban a fogyatékossággal élők jogaihoz Bárd Petra: A fogyatékossággal élő személyek jogai. In Jakab András et al. (szerk.): Internetes Jogtudományi Enciklopédia. 2019. Látni kell azonban, hogy kultúrkörönként is jelentősen változhat a fogyatékossággal élők vallásszabadsághoz való jogának biztosítása. Petruska Ferenc: A vallásszabadság jogának keretei keleten és nyugaton. In Kaló József - Ujházi Lóránd (szerk.): Budapest-Jelentés a keresztényüldözésről 2018. Budapest, Dialóg Campus, 2018. 173-180.

68 United Nations: A Fogyatékossággal Élő Emberek Esélyegyenlőségek Alapvető Szabályai (1994). 
létrehozott Magyar Fogyatékosügyi Caucus jelentést készített a fogyatékos emberek jogait szabályozó ENSZ-egyezményről. Az egyezményt Magyarország másodikként írta alá (2006. december), és rá két évre a parlament ratifikálta. 2008 májusától hatályos. Az egyezmény alapján ugyanis a részes államoknak mindent meg kell tenni annak érdekében, hogy a fogyatékossággal élő személyek számára másokhoz hasonlóan biztosítsák, hogy „gyakorolhassák a szólásszabadság és a véleménynyilvánítás szabadságának jogát", amelyből levezethető a lelkiismereti és vallásszabadság joga is. ${ }^{69}$

\section{Következtetések}

Egyetlen egy vallás sincs, amely olyan mértékben köteleződött volna el a betegek és így a fogyatékossággal élők irányába, mint a kereszténység. Ennek legkézenfekvőbb oka, hogy maga az alapító, a názáreti Jézus tevékenységének meghatározó részét tette ki a betegségeik miatt a társadalom perifériájára kerültek segítése. A „csodákon" kívül Jézus prédikációinak is integráns részét képezte az irgalmas szeretet gyakorlására való buzdítás. Már a korakeresztény kor számára az igazi keresztény ember ideája abban a személyben öltött testet, aki minél tökéletesebben követi a mesterét. A Krisztus-követésnek pedig elválaszthatatlan részét képezte az irgalmas szeretet gyakorlása. Az egyedi szeretetgyakorlás idővel intézményes tevékenységgel egészült ki. Ez utóbbi a lelkes laikus mozgalmaktól a szerzetesrendeken keresztül a modern karitászhálózatig terjedt. Kánon- és világi jogállásuk, struktúrájuk, az egyházi hierarchiával való kapcsolatuk sokszínűséget mutatott. Az azonban közös volt mindannyiukban, hogy a fogyatékossággal élőket, vagyis a legkiszolgáltatottabbakat akarták segíteni. Tevékenységük érzékenyítette azokat a társadalmakat, amelyekben jelen voltak. ${ }^{70}$

Sajnos a keresztény évszázadokban sem kapták meg mindig a fogyatékossággal élők a kötelező tiszteletet és segítséget. Ez nem jelenti, hogy a későbbiekben változott volna az egyház tanítása, de igaza volt Adolf von Harnacknak, aki felismerte, hogy a kereszténység radikális számbeli növekedésével, bevett, majd államvallássá válásával már többen voltak azok, akik inkább voltak „jószándékúak, mint szentek”. A fogyatékossággal élőkkel szembeni heroikus magatartást nyilván a „szentek” gyakorolták. Azonban az általános jóindulatot az egyház mindenkitől elvárta. Ezt a pozitív attitűdöt igyekezett előmozdítani a jámbor prédikációkkal, mély teológiai írásokkal és homíliákkal, illetve példaképformálással. Ez leginkább a társadalom legkülönbözőbb platformjairól származó szenteken keresztül történt. A társadalmak érzékenyítésében nem elhanyagolható a keresztény művészetek hatása sem, amelyek átjárták az európai emberek mindennapjait. Az irgalmas szeretet megkapó ábrázolásait látták a templomokban, a képtárakban, a köztereken, de nem volt ritka, hogy az apostolok lábát mosó Krisztus, vagy a béna koldust betakaró Szent Márton képe

69 Magyar vonatkozásban: 30/1992. AB határozat.

70 Ujházi Lóránd: A világi törvények átvétele a kánonjogba - A kanonizáció intézménye (22. Kán.). Iustum Aequum Salutare, 3. (2013), 4. 143-167; Harnack (1902): i. m. 
tekintett le a családra az ebédlőben. A II. vatikáni zsinat fényében az egyház az állami és a nemzetközi szervezetekben partnert lát a közjó előmozdítása érdekében. Szép és nemes területe az együttműködésnek a fogyatékossággal élők életének segítése, amely mind az egyetemes egyház, mind a részegyház területén, elméleti és gyakorlati síkon egyaránt megvalósul. Amellett, hogy az elmondottakból látszik, hogy nem túlzás azt állítani, hogy a demokratikus jogállamok a 20. század végére felzárkóztak mentalitásukban az egyház tanításához, és eljutottak a pozitív diszkrimináció elvéhez, még mindig vannak olyan területek, ahol a legtöbb állami és nemzetközi jogalkotás és az egyház koncepciója nem találkozik. Ennek tipikus példája a fogyatékossággal születendő gyermekek abortálásának lehetősége. Remélhető, hogy egyszer majd ezen a területen is beéri az állami és a nemzetközi trend az egyház koncepcióját, és az előreláthatóan fogyatékossággal születendő gyermekeket is nagyobb védelemben részesíti.

\section{Irodalomjegyzék}

II. János Pál: Enc. Laborem exercens 1981. IX. 14. Acta Apostolicae Sedis, 73. (1981), 9. 577-647.

II. János Pál: Sollicitudo rei socialis 1987. XII. 30. 80. (1988), 5. 513-586.

II. János Pál: Enc. Redemptoris missio 1990. XII. 7. Acta Apostolicae Sedis, 89. (1990), 249-340.

II. János Pál: Centesimus annus 1991. V. 1. Acta Apostolicae Sedis, 83. (1991), 10. 793-867.

II. János Pál: Enc. Evangelium Vitae 1995. március 25. Acta Apostolicae Sedis, 87. (1995), 5. 401-522.

VI. Pál: Enc. Populorum progressio 1967. III. 26. Acta Apostolicae Sedis, 59. (1967), 257-299.

VI. Pál: Octogesima adveniens 1971. V. 14. Acta Apostolicae Sedis, 63. (1971), 8. 401-444.

XI. Pius: Enc. Casti Connubii, 1930. XII. 31. Acta Apostolicae Sedis, 22. (1930), 12. 539-592.

XI. Pius: Enc. Quadragesimo anno. 1931. V. 15. Acta Apostolicae Sedis, 23. (1931), 6. 177-285.

XIII. Leó: Enc. Rerum novarum. 1891. V. 15. Acta Sanctae Sedis, 23. (1891), 641-670.

XVI. Benedek: Enc. Deus Caritas est. 2005. XII. 22. Acta Apostolicae Sedis, 98. (2006), 3. 217-279.

XVI. Benedek: Esort. Post. Synod. Sacramentum caritatis. 2007. II. 22. Acta Apostolicae Sedis, 99. (2007), 3. 105-180.

XVI. Benedek: Názáreti Jézus. Budapest, Szent István Társulat, 2011.

XVI. Benedek: Litt. Ap. MP. Intima Ecclesiae natura. 2012. XI. 11. Acta Apostolicae Sedis, 104. (2012), 12. 996-1004.

XXIII. János: Enc. Mater et magistra, 1961. V. 15. Acta Apostolicae Sedis, 53. (1961), 401-464.

Anderson, Paul N. - Felix Just - Tom Thatcher: John, Jesus, and History. Aspects of Historicity in the Fourth Gospel. Atlanta, Society of Biblical Literature, 2009.

Bárd Petra: A fogyatékossággal élő személyek jogai. In Jakab András - Könczöl Miklós - Menyhárd Attila - Sulyok Gábor (szerk.): Internetes Jogtudományi Enciklopédia. 2019. Online: http://real. mtak.hu/94351/1/a-fogyatekossaggal-elo-szemelyek-jogai.pdf

Bultmann, Rudolf: Geschichte und Eschatologie. Tübingen, J. C. B. Mohr, 1964.

Bultmann, Rudolf: Glauben und Verstehen. Tübingen, J. C. B. Mohr, 1966.

Beck, Roger: The Religion of the Mithras Cult in the Roman Empire. Oxford, Oxford University Press, 2006. Online: https://doi.org/10.1093/acprof:oso/9780199216130.001.0001

Boeckl, Christine M.: Images of Leprosy Disease, Religion, and Politics in European Art. Kirksville, Missouri, Truman State University Press, 2011. Online: https://doi.org/10.1515/9780271091242 
Dalla Torre, Giuseppe: La città sul monte. Contributo ad una teoria canonistica sulle relazioni tra Chiesa e comunità politica. Roma, AVE, 1996.

Davies, T. Wytton: Bible Leprosy. The Old and New Testament Student, 11. (1890), 3. 142-152. Online: https://doi.org/10.1086/470564

De Voragine, Jacobus: Legenda aurea. Budapest, Neumann Kht., 2004.

Erdő Péter: A püspöki kar szerepe a modern államban. Vigília, 63. (1998), 1. 2-8.

Esposito, Anna - Andreas Rehberg: Gli ordini ospedalieri tra centro e periferia. Roma, Ricerche dell'Istituto Storico Germanico di Roma, 2007.

Falus Orsolya: Ispotályos keresztes lovagrendek az Árpád-kori Magyarországon. Doktori (PhD-) értekezés. Pécs, Pécsi Tudományegyetem Állam- és Jogtudományi Kar, 2014. Online: https://pea. lib.pte.hu/handle/pea/16041?show=full

Ferenc pápa: Amoris Laetitia, Szent István Társulat, Budapest. 2016. Online: https://katolikus.hu/ media/ferenc_papa_amoris_laetitia_2016.pdf

Ferenc pápa: Motu proprio. Humanam progressionem. Vatican News, 2016. augusztus 17. Online: https://w2.vatican.va/content/francesco/it/apost_letters/documents/papa-francesco-letteraap_20160817_humanam-progressionem.html

Ferenc pápa: Az abortusz a gyermekek meggyilkolása. Magnificat, 2018. június 19. Online: www. magnificat.ro/portal/index.php/hu/koezoes-ertekeink/17340-ferenc-papa-az-abortusz-a-gyermekek-meggyilkolasa

Ferenc pápa: Fratelli Tutti. Vatican, 2020. október. 3. Online: www.vatican.va/content/francesco/it/ encyclicals/documents/papa-francesco_20201003_enciclica-fratelli-tutti.html

Gedő Ágnes: Pápai üzenet a fogyatékossággal élők világnapjára: Befogadóbb világot építsünk a járvány után. Vatican News, 2020. december 5. Online: www.vaticannews.va/hu/papa/news/202012/papai-uzenet-a-fogyatekkal-elok-vilagnapjara-befogadobb-vilag.html

Gibson, Walter S.: Pieter Bruegel and the Art of Laughter. Berkeley, University of California Press, 2006.

González, Justo: Faith and Wealth: A History of Early Christian Ideas on the Origin, Significance, and Use of Money. San Francisco, Harper and Row, 1990.

Hebda, Bernard A.: Where Canon Law Connects with Caritas: The Norms of Intima Ecclesiae Natura. A Year of Mercy Examination of Challenges to Compliance in a US Context. The Jurist, 76. (2016), 2. 339-359. Online: https://doi.org/10.1353/jur.2016.0022

Holy See cannot Join Convention on Disabled People. Cirkev, 2007. február 1. Online: www.cirkev. cz/archiv/070201-holy-see-cannot-join-convention-on-disabled-people

Hulse, E. V.: The Nature of Biblical 'Leprosy' and the Use of Alternative Medical Terms in Modern Translations of the Bible. Palestine Exploration Quarterly, 107. (1975), 2. 87-105. Online: https://doi.org/10.1179/peq.1975.107.2.87

Iannone, Filippo: Curia Romana Semper Reformanda Le riforme postconciliari. Asprenas, 67. (2020), 1. 5-27.

Kálmán Zsófia - Könczei György: A Taigetosztól az esélyegyenlöségig. Budapest, Osiris, 2012.

Kempis Tamás: Krisztus követése. Esztergom, Ecclesia, [1493] 1976.

Klenar, Matjaž Muršič: Možnosti dialoga v sodobni sekularni družbi. Abstract Possibilities of Dialogue in the Modern Secular Society. Bogoslovni Vestnik, 80. (2020), 3. 575-584. Online: https:// doi.org/10.34291/BV2020/03/Mursic

Knight A. John: The Holiness Pilgrimage. Kansas City, Beacon Hill, 1986.

Kovacs Judith - Rowland Christopher: Revelation: The Apocalypse of Jesus Christ. Oxford, Blackwell Bible Commentaries, 2004. 
Kriskó Edina: Fogyatékokkal élőkkel történő bánásmód a hivatalban. Budapest, Nemzeti Közszolgálati Egyetem, 2014.

Krutsay Miklós: Betegápoló szerzetesrendek. Osteologiai Közlemények, 26. (2018), 1-2. 52-54.

Levison, Wilhelm: Zur Vorgeschichte der Bezeichnung Servus servorum Dei. Zeitschrift der Savigny-Stiftung für Rechtsgeschichte. Kanonistische Abteilung, 6. (1916), 1. 384-386. Online: https:// doi.org/10.7767/zrgka.1916.6.1.384

Life (Explores): Jesus How His Lessons, Miracles and Devotion Changed the World. 2019. december 6 .

Loveday, Alexander: The Preface to Luke's Gospel Literary Convention and Social Context in Luke 1.1-4 and Acts 1.1. Cambridge, Cambridge University Press, 1993.

Lumpkin, Joseph: The Apocrypha: Including Books from the Ethiopic Bible. Blountsville, Fifth Estate Publishers, 2009a.

Lumpkin, Joseph: Lost Books of the Bible: The Great Rejected Texts. Blountsville, Fifth Estate Publishers, 2009b.

Magyar Civil Caucus: Fogyatékos személyek jogai vagy fogyatékos jogok? Budapest, SINOSZ MDAC - FESZT, 2010.

Magyar Kurír: Párizs orvos végzettségü érseke a fogyatékossággal élők integrációjáért küzd (2020. január 12.). Online: www.magyarkurir.hu/kitekinto/parizs-orvos-vegzettsegu-erseke-fogyatekkal-elok-integraciojaert-kuzd

Malina, Bruce J.: The Social World Of Jesus and the Gospels. London - New York, Routledge, 1996.

Maróth Miklós: A nesztorianizmus - elveszett keresztény közösség: tanulságok napjaink vallásközi párbeszédjéhez. Az előadás elhangzott a Keresztényüldözés a történelemben című konferencián 2019. április 11. Helyszín: NKE Hadtudományi és Honvédtisztképző Kar Zrínyi Miklós Laktanya és Egyetemi Campus, Díszterem.

Masters, Anne: An Opportunity for Charity? A Catholic Tradition in Understanding Disability and its Impact on Ministry. Journal of Disability \& Religion, 20. (2016), 3. 218-227. Online: https:// doi.org/10.1080/23312521.2016.1207216

Miñambres, Jesús: Considerazioni sulla provvista di uffici ecclesiastici per presentazione premessa nel codice del 1983. Ius Ecclesiae, 11. (1999), 407-418. Online: https://dadun.unav.edu/bitstream/10171/17171/1/IC_Especial_1999_32.pdf

Muir, C. Steven: "Look How They Love One Another": Early Christian and Pagan Care for the Sick and Other Charity. In Vaage, E. Leif (szerk.): Religious Rivalries in the Early Roman Empire and the Rise of Christianity. (h. n.), Wilfrid Laurier University Press, 2006. 213-232.

Navarro, Luis: Le iniziative dei fedeli nel servizio della carità. Fondamento e configurazione giuridica. In Jesús Miñambres (szerk.): Diritto canonico e Servizio della carità. Milano, Giuffrè, 2008. 193-223.

Pennington, Jonathan T.: Heaven and Earth in the Gospel of Matthew. Leiden-Boston, Brill, 2007. Online: https://doi.org/10.1163/ej.9789004162051.i-399

Petruska Ferenc: A vallásszabadság jogának keretei keleten és nyugaton. In Kaló József - Ujházi Lóránd (szerk.): Budapest-jelentés a keresztényüldözésröl 2018. Budapest, Dialóg Campus, 2018. 173-180.

Roman Empire and the Rise of Christianity. (h. n.), Wilfrid Laurier University Press, 2006. 3-20.

Rozen, Barbara - Maksym Adam Kopiec: Le persone disabili nell'economia della salvezza di Dio.

Forum Teologiczne, 20. (2019). 109-125. Online: https://doi.org/10.31648/ft.4808

Russell, Peter: Complete Works of Pieter Bruegel the Elder. Kindle edition, 2016. 
Schanda Balázs: Magyarország keresztény kultúrájáról. Pázmány Law Working Papers 2018/08. Budapest, Pázmány Péter Katolikus Egyetem, 2018. Online: https://plwp.eu/files/2018/PLWP_201808_Schanda.pdf

Schweitzer Gábor: Becsüljük országunk különböző vallási hagyományait. In Patyi András (szerk.): Rendhagyó kommentár egy rendhagyó preambulumról. Magyarország Alaptörvénye, Nemzeti hitvallás. Budapest, Dialóg Campus, 2019. 107-121.

Szűcs Kata: A Szent Erzsébet-kultusz Magyarországon és Portugáliában. In Adsumus XII. Tanulmányok a XIV. Eötvös Konferencia elöadásaiból. Budapest, Eötvös Collegium, 2014. 115-135.

Taveirne, Maarten: Das Martyrium als imitatio Christi: Die literarische Gestaltung der spätantiken Märtyrerakten und -passionen nach der Passion Christ. Zeitschrift für Antikes Christentum/ Journal of Ancient Christianity, 18. (2014), 2. 167-203. Online: https://doi.org/10.1515/zac2014-0010

Tertullianus: Apologeticus.

Ujházi Lóránd: A világi törvények átvétele a kánonjogba - A kanonizáció intézménye (22. Kán.). Iustum Aequum Salutare, 3. (2013), 4. 143-167. Online: http://ias.jak.ppke.hu/hir/ias/20103sz/ 10.pdf

Ujházi Lóránd: A szentszéki strukturális és jogszabályi módosítások az európai migrációs válság fényében. Acta Humana - Emberi Jogi Közlemények, 5. (2017), 2. 19-41. Online: https://doi. org/10.32566/ah.2017.2.2

Ujházi, Lóránd: The Significance of Charity (Caritas) in the Governing, Sanctifying, and Teaching Mission of the Church. Bogoslovni Vestnik, 80. (2020), 4. 783-802. Online: https://doi. org/10.34291/BV2020/04/Ujhazi

Ujházi Lóránd - Kliszek Németh Noémi: A szerzetestől és püspöktől a katonáig, avagy a Szent Márton kultusz formálódása. Felderitö Szemle, 15. (2016), 4. 32-41. Online: https://www.knbsz.gov.hu/ hu/letoltes/fsz/2016-4.pdf

United Nations: A Fogyatékossággal élő emberek esélyegyenlőségek alapvetö szabályai (1994). Online: https://tamogatosegitseg.hu/pdf/a_fogyatekossaggal_elo_emberek_eselyegyenlosegenek_ alapveto_szabalyai.pdf

Vaage, Leif E.: Ancient Religious Rivalries and the Struggle for Success: Christians, Jews, and Others in the Early Roman Empire. In Leif E. Vaage (szerk.): Religious Rivalries in the Early Roman Empire and the Rise of Christianity. (h. n.), Wilfrid Laurier University Press, 2006.

Vita di Santa Elisabetta. In Domenico Maria Manni (szerk.): Vite di alcuni Santi. Firenze, 1735, 705-726.

Walker, William O.: Demythologizing and Christology. Forum, 3. (2014), 2. 35-45.

Wardle, Timothy: The Jerusalem Temple and Early Christian Identity. Tübingen, Mohr Siebeck, 2010. Online: https://doi.org/10.1628/978-3-16-151634-4

Zsákai Róbert - Horváth László: Az Egyház és a társadalom kapcsolata. Hadmérnök, 8. (2013), 4. 265-271. Online: https://doi.org/10.32567/hm.2013.4.25

\section{Jogforrások}

Magyarország Alaptörvénye

1993. évi III. törvény a szociális igazgatásról és szociális ellátásokról

1998. évi XXVI. törvény a fogyatékos személyek jogairól és esélyegyenlőségük biztosításáról 1999. évi C. törvény az Európai Szociális Karta kihirdetéséről

2003. évi CXXV. törvény az egyenlő bánásmódról és az esélyegyenlőség előmozdításáról 
2007. évi XCII. törvény a Fogyatékossággal élő személyek jogairól szóló egyezmény és az ahhoz kapcsolódó Fakultatív Jegyzőkönyv kihirdetéséről

2009. évi CXXV. törvény a magyar jelnyelvről és a magyar jelnyelv használatáról

30/1992. AB határozat

38/2011. (VI. 29.) NEFMI rendelet a Jelnyelvi Tolmácsok Országos Névjegyzékéről

62/2011. (XI. 10.) NEFMI rendelet a jelnyelvi tolmácsszolgálatok müködésének és a jelnyelvi tolmácsszolgáltatás igénybevételének feltételeiről

2013. évi V. törvény a Polgári Törvénykönyvről

1653/2015. (IX. 14.) Korm. határozat az Országos Fogyatékosságügyi Program végrehajtásának 2015-2018. évekre vonatkozó Intézkedési Tervéről

1257/2011. (VII. 21.) Korm. határozat a fogyatékos személyek számára ápolást-gondozást nyújtó szociális intézményi férőhelyek kiváltásának stratégiájáról és a végrehajtásával kapcsolatos kormányzati feladatokról 